\title{
Long Non-Coding RNA Signature in Cervical Cancer
}

\section{Dlouhé nekódující molekuly RNA u cervikálních nádorů}

\author{
Taheri M. ${ }^{1}$, Ghafouri-Fard S. ${ }^{2}$ \\ 'Student Research Committee, Shahid Beheshti University of Medical Sciences, Tehran, Iran \\ ${ }^{2}$ Department of Medical Genetics, Shahid Beheshti University of Medical Sciences, Tehran, Iran
}

\begin{abstract}
Summary
Background: Cervical cancer as a common urogenital cancer among women has caused significant health problems. Efforts have been made to identify its pathogenic process in order to find targeted therapies. Long non-coding ribonucleic acids (IncRNAs) have been shown to regulate several cancer-related pathways and genes that contribute to pathogenesis of human malignancies, including cervical cancer. In the present review, we searched PubMed, Google scholar, Web of Science and Scopus databases for key words "cervical cancer" or "cervical neoplasm" and "long non-coding RNA" or "IncRNA" (up to December 2017). Aim: To elaborate the role of IncRNAs in cervical cancer. Conclusions: LncRNAs affect cervical cancer pathogenesis through numerous mechanisms, such as making scaffolds for assembly of protein complexes, serving as directors to recruit proteins, functioning as transcriptional enhancers through chromatin remodeling, serving as decoys to free up proteins from chromatin, or reversing the effects of other regulatory non-coding RNAs, such as microRNAs. Pathway-based analysis showed that several IncRNAs modulate PI3K/Akt/mTOR, Wnt- $\beta$ catenin and Notch pathways in the process of cervical cancer pathogenesis. In addition, expression of a handful of IncRNAs has been associated with human papilloma virus infection. Identification of IncRNAs that alter cancer-related signaling pathways and subsequent expression analysis of these IncRNAs in patients' samples would help to design effective targeted therapies.
\end{abstract}

Key words

IncRNA - cervical cancer - oncogene - tumor suppressor gene

\section{Souhrn}

Východiska: Rakovina děložního čípku jako běžný urogenitální nádor způsobuje u žen značné zdravotní problémy. Byla vynaložena snaha o identifikaci patogeneze za účelem nalezení cílených terapií. Bylo prokázáno, že dlouhé nekódující ribonukleové kyseliny (IncRNA) regulují několik signálních drah a genů souvisejících s nádory, což přispívá k patogenezi lidských malignit vč. rakoviny děložního čípku. V rámci prezentovaného článku jsme do prosince 2017 vyhledávali klíčová slova "cervical cancer" (rakovina děložního čípku) nebo "cervical neoplasm" (cervikální novotvar) a "long non-coding RNA“ (dlouhá nekódující RNA) nebo „IncRNA", publikovaná $\checkmark$ databázi PubMed, Google scholar, Web of Science a Scopus. Cil: Zjistit, jakou roli hrají IncRNA $\checkmark$ rakovině děložního čípku. Závěry: LncRNA ovlivňují patogenezi rakoviny děložního čípku prostřednictvím četných mechanismů, jako je vytváření tzv. scaffolds pro sestavení proteinových komplexů, sloužící jako tzv. directors pro získávání proteinů, fungujících jako transkripční zesilovače pomocí remodelování chromatinu, sloužící jako tzv. návnady $\mathrm{k}$ uvolnění proteinů z chromatinu nebo zvrácení účinků jiné regulační nekódující RNA jako jsou mikroRNA. Analýza signálních drah ukázala, že v procesu patogeneze rakoviny děložního čípku několik IncRNA reguluje dráhy PI3K/Akt/mTOR, Wnt- $\beta$ catenin a Notch signální dráhy. Navíc exprese několika IncRNA byla spojena s infekcí virem lidského papilomu. Identifikace IncRNA, které mění signální dráhy související s nádory, a následná expresní analýza těchto IncRNA ve vzorcích pacientů by mohly pomoci získat efektivní cílené terapie.

\section{Klíčová slova}

IncRNA - nádor děložního čípku - onkogen - tumor supresorový gen
The authors declare they have no potential conflicts of interest concerning drugs, products, or services used in the study.

Autoři deklarují, že $v$ souvislosti s predmětem studie nemaji žádné komerční zájmy.

The Editorial Board declares that the manuscript met the ICMJE recommendation for biomedical papers.

Redakční rada potvrzuje, že rukopis práce splnil ICMJE kritéria pro publikace zasílané do biomedicínských časopisů.

Soudeh Ghafouri-Fard, MD, PhD Department of Medical Genetics Shahid Beheshti University of Medical Sciences Bldg No. 2 SBUMS

Arabi Ave, Daneshjoo Blvd, Velenjak Tehran, Iran

e-mail: s.ghafourifard@sbmu.ac.ir

Submitted/Obdrženo: 25. 4. 2018

Accepted/Přijato: 1. 11.2018

doi: $10.14735 / a m k o 2018403$ 


\section{Introduction}

In recent years, progress in genome analyses has led to recognition of an evolving class of non-coding ribonucleic acids (ncRNAs) that participate in the modulation of gene expression and epigenetic reprogramming [1]. A significant number of these ncRNAs are longer than 200 nucleotides and instead of being transcriptional "noise", they use various routes to control gene expression [1]. These so-called long non-coding RNA (IncRNAs) have tissue specific expression pattern [2] but are less conserved than protein coding RNAs [3]. They are involved in almost every aspect of physiological processes, such as preservation of DNA integrity [4], telomere biology [5], immune cell homeostasis [6], regulation of hormone receptors [7] as well as differentiation and homeostasis of metabolic tissues [8]. The differential expression of IncRNAs in malignant tissues compared with normal tissues of the same origin has been demonstrated in several studies [3,9-14] what implies their role in pathogenesis of different cancers. Such speculation has been further supported by the presence of distinct single nucleotide polymorphisms within IncRNA coding genes which alter the risk of cancer development $[15,16]$.

Cervical cancer as a common urogenital cancer among women is mostly associated with human papilloma virus (HPV) infection. However, as its incidence is much lower than the prevalence of HPV infection, other factors are thought to have synergic effects with HPV infection to induce cervical cancer [17]. Dysregulation of Wnt/ $\beta$-catenin signaling as well as PI3K/Akt/mTOR signaling pathway have also been implicated in the pathogenesis of cervical cancer [18]. Considering the role of IncRNAs in the regulation of these pathways, we searched the literature to identify IncRNAs that modulate cervical cancer risk especially through alteration of these pathways or through modulation of HPV infection process.

\section{Search strategy}

We searched PubMed, Google scholar, Web of Science and Scopus databases with the key words "cervical cancer" or "cervical neoplasm" AND "long non-coding RNA" or "IncRNA". Original articles were chosen if they were written in English and had enough number of samples for expression analysis (at least 20 patients' samples from exclusive clinical studies) and described the mechanism of IncRNA involvement in cervical cancer (for in vitro studies). Other types of papers were excluded from the study. Papers, which focused on analysis of IncRNAs at genomic level, were also excluded.

\section{LncRNA involvement \\ in cervical cancer}

A recent study aimed at identification of expression profiles of IncRNAs, circular RNAs, microRNA (miRNA), and messenger RNA (mRNA) in HPV16 mediated cervical squamous cell carcinoma have found 19 IncRNAs that are frequently differentially expressed in cervical cancer samples compared to normal samples. Such differentially expressed IncRNAs have been shown to participate in cervical cancer pathogenesis as revealed by the co-expression network and function prediction [19]. In addition to this high throughput studies, several studies have assessed the significance of IncRNAs in cervical cancer pathogenesis. Based on the importance of HPV infection and dysregulation of signaling pathways in the pathogenesis of cervical cancer, we subsequently analyzed IncRNAs based on their involvement in one of these mechanisms.

\section{LncRNAs and HPV infection}

HPVs as double-stranded circular DNA viruses encode several proteins, which participate in their DNA replication, gene transcription and cellular transformation. E6 and E7 proteins coded by high-risk HPV viruses participate in the pathogenesis of HPV-associated carcinomas [20]. Degradation of p53 and retinoblastoma protein ( $\mathrm{Rb})$ as two important tumor suppressor proteins is induced by the HPV oncogenic proteins E6 and E7, respectively. E6 also participates in carcinogenesis through induction of telomerase activation, while E7 alters the expression of synthesis phase genes by directly disturbing $\mathrm{pRb} / \mathrm{E} 2 \mathrm{~F}$ complex and enhances cell survival by inducing expression of interleukin-648 and antiapoptotic $\mathrm{Mcl}-126$ and triggering the Akt/PKB pathway [20]. The cooperation of HPV oncogenes and IncRNAs in cervical cancer context has been first revealed for metastasis-associated lung adenocarcinoma transcript 1 (MALAT1). This IncRNA has been over-expressed in cervical cancer cell lines compared with normal cervical squamous cell samples. However, its expression has been decreased following the E6/E7 knockdown in CaSki cells. Further assessment of clinical samples has confirmed exclusive expression of MALAT1 in HPV-positive cervical squamous cells, but not in HPV-negative normal cervical squamous cells [21]. The positive association between MALAT1 expression levels and HPV infection has also been documented in cervical epithelial tissues by microarray analysis [22].

HOX transcript antisense RNA (HOTAIR) participates in epigenetic regulation of gene expression through recruitment of chromatin remodeling polycomb repressive complex 2 (PRC2). This IncRNA has been recognized as a target of E7 in HPV16 related cervical cancers. HOTAIR expression has been shown to be progressively decreased in a linear manner from HPV negative controls to HPV16 positive non-malignant and cervical cancer samples. Such downregulation was concomitant with upregulation of HOTAIR target, HOXD10, and enhancement of cancer related pathways in most cervical cancer cases. Conversely, a minority of them had considerably higher HOTAIR expression, associated with high E7 expression and enhancement of metastatic pathways. The interaction between HOTAIR and E7 has further been supported by observation of a positive correlation between E7 expression and expressions of both HOTAIR and PRC2 complex members (EZH2 and SUZ12) in cervical cancer cases. In addition, both in silico analysis and RNA immunoprecipitation endorsed the functional inactivation of HOTAIR by direct interaction with E7. Consequently, HOTAIR has been 


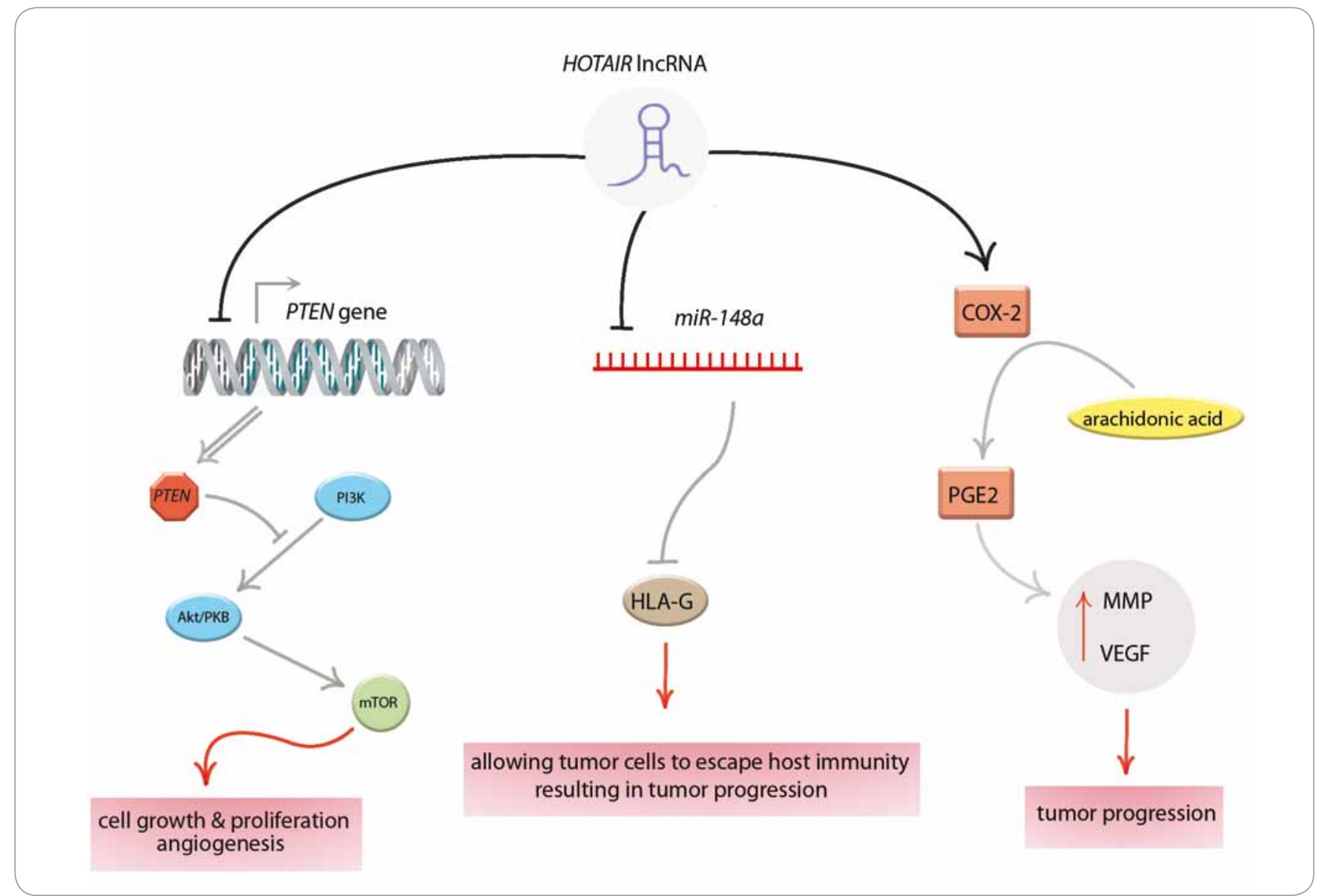

Schema 1. Different roles of HOTAIR in cervical cancer tumorigenesis: HOTAIR has a negative regulatory role on PTEN tumor suppressor gene. HOTAIR role in EMT is due to its effect on COX-2 stabilization which leads to induction of MMPs and VEGF. HOTAIR also enhances HLA-G associated immune escape by competitively binding to miR-148a.

IncRNA - long non-coding ribonucleic acid, EMT - epithelial-mesenchymal transition, MMP - matrix metallopeptidase, VEGF - vascular endothelial growth factor, HLA-G - human leukocyte antigen G, PGE2 - prostaglandin E2, COX - cyclooxygenase

identified as a downstream target of HPV16 E7 in the process of cervical cancer pathogenesis [23].

\section{LncRNAs and PI3K/Akt/mTOR pathway}

Maternally expressed 3 (MEG3) as a tumor suppressor IncRNA has been implicated in cervical cancer. Its over-expression in cervical cancer cells resulted in down-regulation of PI3K, Akt, MMP-2, MMP-9 and $\mathrm{BCl}-2$ expression while upregulating Bax and P21 expression. Consequently, IncRNA MEG3 inhibits cervical cancer by modification of PI3K/ Akt/Bcl-2/Bax/P21 and PI3K/Akt/MMP-2/9 signaling pathway [24]. GAS5 as another tumor suppressor has been shown to modulate cellular growth and drug resistance through the PTEN/PI3K/
Akt/mTOR pathway. The low level of GAS5 leads to PTEN down-regulation by interacting with miR-21 because PTEN is one of the genes in the PI3K/Akt/mTOR pathway whose expression is decreased by GAS5. Eventually, the low expression of PTEN triggers the PI3K/Akt pathway, therefore producing a circulation. Moreover, GAS5 and miR-21 modulate cisplatin resistance in cervical cancer cells via the PI3K/Akt pathway [25].

\section{Mitogen activated protein kinases (MAPK) pathway}

TCONS_00026907 as a newly identified IncRNA enhances expression of cyclin $\mathrm{D} 1$ and $\mathrm{BCl}-2$ in vivo and in vitro. Its knockdown inhibits growth of cervical tumors and modulates the expression of ELK1, p-ELK1, c-fos, cyclin D1 and Bcl-2 in vivo.
Considering the role of ELK1 as a nuclear target for the Ras-Raf-MAPK signaling cascade [26], the oncogenic effect of this IncRNA in cervical cancer might be due to its effect on MAPK pathway.

\section{LncRNAs and Wnt/ $\beta$-catenin pathway}

The Wnt/ $\beta$-catenin signaling pathway is a quintessential survival pathway which modulates several cellular processes including proliferation, growth, survival and metabolism. XIST silencing in cervical cancer cells decreased the protein level of $\beta$-catenin and inhibited the protein expression of two Wnt/ $\beta$-catenin downstream genes - cyclin D1 and c-Myc [27]. Besides, CCAT-1 role in enhancement of proliferation and suppression of apoptosis of cervical cancer cells is also 

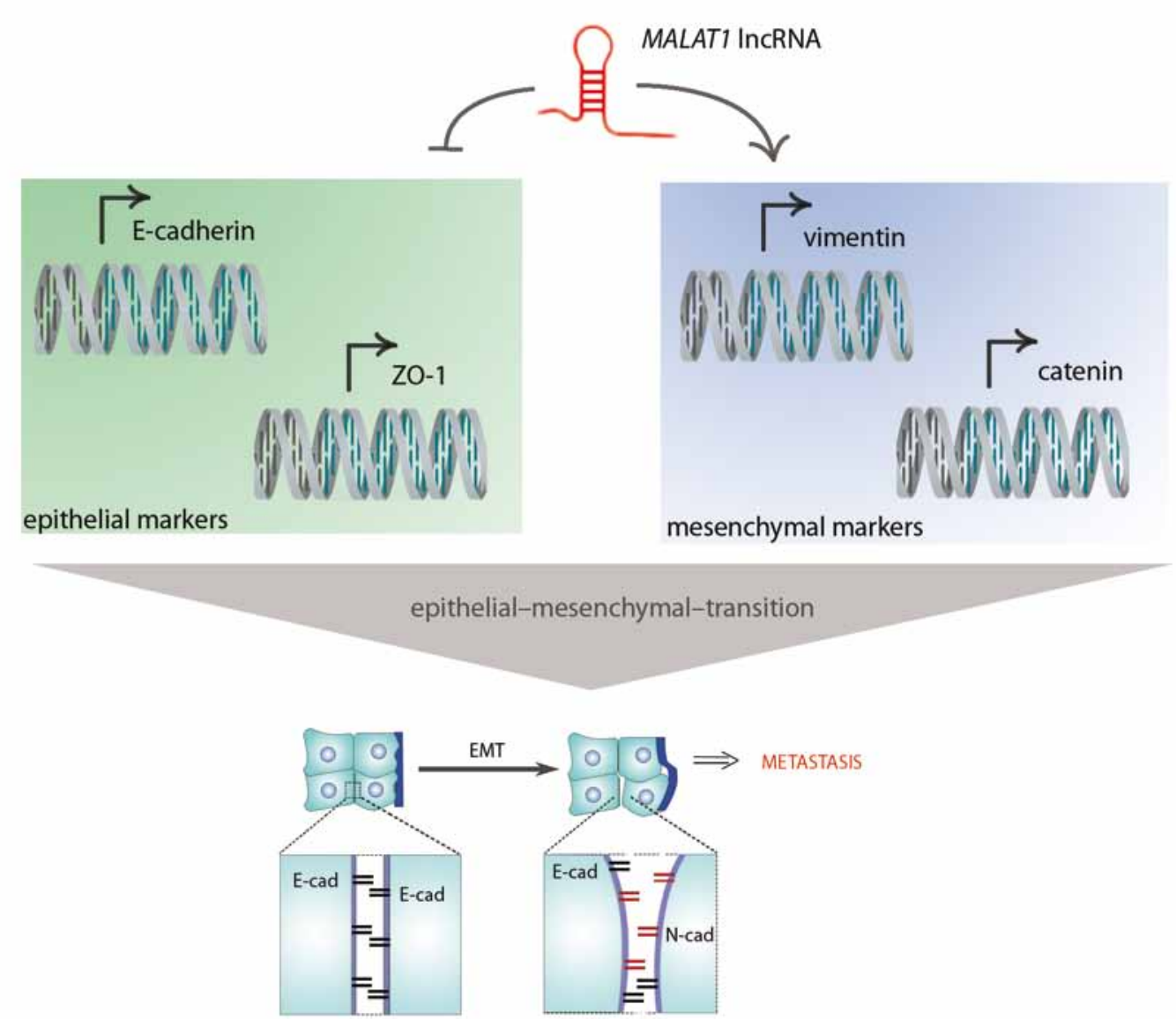

Schema 2. MALAT1 role in cervical cancer: MALAT1 inhibits epithelial markers E-cadherin and ZO-1, and simultaneously enhances expression of the mesenchymal markers $\beta$-catenin and vimentin as well as the Snail transcription factor.

IncRNA - long non-coding ribonucleic acids, EMT - epithelial-mesenchymal transition, E-cad - E-cadherin

through induction of the $\mathrm{Wnt} / \beta$-catenin pathway [28].

\section{LncRNAs and Notch pathway}

Evaluation of the essential signaling cascades regulated by Notch in HOTAIR-overexpressing cells has shown that HOTAIR overexpression in SiHa cells has led to increased NOTCH1, HES1 and p300 expression [29].

LncRNA involvement in epithelialmesenchymal transition (EMT) of cervical cancer cells

HOTAIR as an oncogenic IncRNA in cervical cancer has been shown to alter the expression of several genes participated in cell migration, invasion and EMT, such as vascular endothelial growth factor, MMP-9, E-cadherin, $\beta$-catenin, vimentin, Snail and Twist [30]. EMT-related levels have also been elevated in xenografts originated from
HOTAIR-overexpressing SiHa cells compared with the control tumors [29]. In addition, HOTAIR enhances migration and invasion of HeLa cervical cancer cells, at least partially, through the modulation of vimentin expression [31]. HOTAIR role in EMT might also due to its effect on COX-2 stabilization, which leads to induction of matrix metalloproteinases and vascular endothelial growth factor (Schema 1) [32].

MALAT1 exerts its role in cervical cancer cell invasion and metastasis by enhancement of the EMT process through increasing the expression of Snail [33]. MALAT1 silencing suppressed the invasion and metastasis of cervical cancer cells, increased expression of the epithelial markers E-cadherin and ZO-1, and simultaneously decreased expression of mesenchymal markers $\beta$-catenin and vimentin as well as the Snail transcription factor (Schema 2) [22].
The IncRNA taurine-upregulated gene 1 (TUG1) was also shown to increase migration and invasion of cervical cancer cells by modulating EMT-related markers such as fibronectin, vimentin and cytokeratin [34].

HOXA11-AS has also been shown to participate in EMT. HOXA11-AS silencing has led to increase in $\mathrm{E}$-cadherin expression while decreasing levels of $\beta$-catenin, vimentin and the EMT-mediating transcription factor Snail [35].

In addition, EZH2-binding IncRNA in cervical cancer (IncRNA-EBIC) has a role in migration and invasion of cervical cancer cells through modulation of E-cadherin [36].

\section{LncRNAs role in cervical cancer immune evasion}

The human leukocyte antigen-G (HLA-G) as a member of the non-classical major histocompatibility complex family 
is recruited by cancer cells to beat attentive immuno-surveillance of the host. HOTAIR has been shown to enhance HLA-G associated immune escape by competitively binding to miR-148a (Schema 1) [37].

\section{Discussion}

Consistent with diverse mechanisms of IncRNAs participation in regulation of gene expression, IncRNAs can affect cervical cancer pathogenesis through various mechanisms. Overall, the regulatory function of IncRNAs can be exerted through making scaffolds for assembly of protein complexes, serving as guides to recruit proteins, functioning as transcriptional enhancers through chromatin remodeling, serving as decoys to free up proteins from chromatin, or reversing the effects of other regulatory ncRNAs, such as miRNAs [38]. Besides, the expression of HPV oncogenes as the most important causal factor in cervical cancer has been shown to be linked to expression levels of some IncRNAs. However, functional studies to reveal the exact mechanism of this association has been performed for only two IncRNAs, namely MALAT1 and HOTAIR. Moreover, expression of several IncRNAs has been shown to be dysregulated in tumor tissues as well as plasma samples from cervical cancer patients. Higher expression of certain IncRNAs in the plasma of cervical cancer patients compared to healthy subjects provides an applicable tool for screening and follow-up of patients.

More importantly, methylation pattern of the MEG3 IncRNA has been demonstrated to be a diagnostic and prognostic marker of cervical cancer with the capability to predict high-risk HPV infection and lymph node metastasis [39]. Considering the early onset of methylation alterations during carcinogenesis, identification of such marks is valuable in early detection of cancer.

Notable, several IncRNAs have been shown to affect cancer-related pathways. Alterations in these pathways modulate response to conventional chemotherapeutic approaches as revealed for cisplatin resistance in cervical can- cer [25]. On the other hand, dysregulation of numerous signaling pathways, such as Notch and mTOR pathways, has been demonstrated in cervical cancers through transcriptome analysis. Considering the therapeutic potential of these signaling pathways in at least some types of cervical cancer, targeted inhibition of Notch and mTOR pathways has been suggested as therapeutic options for cervical cancer patients [40]. Consequently, identification of IncRNAs that alter these signaling pathways and subsequent expression analysis of these IncRNAs in patients' samples would help to better select patients for recruitment in these trials.

\section{References}

1. Wan DC, Wang KC. Long noncoding RNA: significance and potential in skin biology. Cold Spring Harb Perspec Med 2014; 4(5): pii: a015404. doi: 10.1101/cshperspect. a015404.

2. Dianatpour A, Ghafouri-Fard S. Long non coding RNA expression intersecting cancer and spermatogenesis: a systematic review. Asian Pac J Cancer Prev 2017; 18(10): 2601-2610. doi: 10.22034/APJCP.2017.18.10.2601.

3. Soudyab M, Iranpour M, Ghafouri-Fard S. The role of long non-coding RNAs in breast cancer. Arch Iran Med 2016; 19(7): 508-517. doi: 0161907/AIM.0011.

4. Dianatpour A, Ghafouri-Fard S. The role of long non coding RNAs in the repair of DNA double strand breaks. Int J Mol Cell Med 2017; 6(1): 1-12.

5. Oliva-Rico D, Herrera LA. Regulated expression of the InCRNA TERRA and its impact on telomere biology. Mech Ageing Dev 2017; 167: 16-23. doi: 10.1016/j. mad.2017.09.001

6. Mowel WK, Kotzin JJ, McCright SJ et al. Control of immune cell homeostasis and function by IncRNAs. Trends Immunol 2018; 39(1): 55-69. doi: 10.1016/j.it.2017.08.009. 7. Faramarzi S, Dianatpour A, Ghafouri-Fard S. Discover ing the role of long non-coding RNAs in regulation of steroid receptors signaling in cancer. J Biol and Today's World 2017; 6(12): 248-258. doi: 10.15412/J.JBTW.01061202.

8. Kornfeld JW, Brüning JC. Regulation of metabolism by long, non-coding RNAs. Front Genet 2014; 5: 57. doi: 10.3389/fgene.2014.00057.

9. Iranpour M, Soudyab M, Geranpayeh L et al. Expression analysis of four long noncoding RNAs in breast cancer. Tumour Biol 2016; 37(3): 2933-2940. doi: 10.1007/s13277015-4135-2.

10. Nikpayam E, Tasharrofi B, Sarrafzadeh S et al. The role of long non-coding RNAs in ovarian cancer. Iran Biomed J 2017; 21(1): 3-15. doi: 10.6091/.21.1.24.

11. Nikpayam E, Soudyab M, Tasharrofi B et al. Expression analysis of long non-coding ATB and its putative target in breast cancer. Breast Dis 2017; 37(1):11-20. doi 10.3233/BD-160264.

12. Taheri M, Omrani MD, Ghafouri-Fard S. Long noncoding RNAs expression in renal cell carcinoma. J Bio Today's World 2017; 6(12): 240-247. doi: 10.15412/J. JBTW.01061201

13. Tasharrofi B, Soudyab M, Nikpayam E et al. Comparative expression analysis of hypoxia-inducible factor-alpha and its natural occurring antisense in breast cancer tissues and adjacent noncancerous tissues. Cell Biochem Funct 2016; 34(8): 572-578. doi: 10.1002/cbf.3230.
14. Taheri M, Omrani MD, Ghafouri-Fard S. Long non-coding RNA expression in bladder cancer. Biophys Rev 2017; 10(4): 1205-1213. doi: 10.1007/s12551-017-0379-y. 15. Taheri M, Habibi M, Noroozi R et al. HOTAIR genetic variants are associated with prostate cancer and benign prostate hyperplasia in an Iranian population. Gene 2017; 613: 20-4. doi: 10.1016/j.gene.2017.02.031

16. Taheri M, Pouresmaeili F, Omrani MD et al. Association of ANRIL gene polymorphisms with prostate cancer and benign prostatic hyperplasia in an Iranian population. Biomark Med 2017: 11(5): 413-422. doi: 10.2217/bmm2016-0378.

17. Motevaseli E, Azam R, Akrami SM et al. The effect of lactobacillus crispatus and lactobacillus rhamnosusculture supernatants on expression of autophagy genes and HPV E6 and E7 oncogenes in the HeLa cell line. Cell J 2016; 17(4): 601-607.

18. Taherian-Esfahani Z, Abedin-Do A, Nouri Z et al. Lactobacilli differentially modulate $\mathrm{mTOR}$ and Wnt/B-catenin pathways in different cancer cell lines. Iran J Cancer Prev 2016; 9(3): e5369. doi: 10.17795/ijcp-5369.

19. Wang $H$, Zhao $Y$, Chen $M$ et al. Identification of novel long non-coding and circular RNAs in human papillomavirus-mediated cervical cancer. Front Microbiol 2017; 8: 1720. doi: 10.3389/fmicb.2017.01720

20. Goedert L, Plaça JR, Nunes EM et al. Long noncoding RNAs in HPV-induced oncogenesis. Adv Virol 2016; 6: 1. doi: 10.4137/ATV.S29816.

21. Jiang Y, Li Y, Fang $S$ et al. The role of MALAT1 correlates with HPV in cervical cancer. Oncol Lett 2014; 7(6): 2135-2141. doi: 10.3892/ol.2014.1996.

22. Sun R, Qin C, Jiang B et al. Down-regulation of MALAT1 inhibits cervical cancer cell invasion and metastasis by inhibition of epithelial-mesenchymal transition. Mol Biosyst 2016; 12(3): 952-962. doi: 10.1039/c5mb00685f. 23. Sharma S, Mandal P, Sadhukhan T et al. Bridging links between long noncoding RNA HOTAIR and HPV oncoprotein E7 in cervical cancer pathogenesis. Sci Rep 2015; 5: 11724. doi: 10.1038/srep11724

24. Wang X, Wang Z, Wang J et al. LncRNA MEG3 has anti-activity effects of cervical cancer. Biomed Pharmacother 2017; 94: 636-643. doi: 10.1016/j.biopha.2017.07.056. 25. Wen Q, Liu Y, Lyu H et al. Long noncoding RNA GAS5, which acts as a tumor suppressor via microRNA 21, regulates cisplatin resistance expression in cervical cancer. Int J Gynecol Cancer 2017; 27(6): 1096-1108. doi: 10.1097/IGC.0000000000001028

26. Jin XJ, Chen XJ, HuY et al. LncRNA-TCONS 00026907 is involved in the progression and prognosis of cervical cancer through inhibiting miR-143-5p. Cancer Med 2017; 6(6): 1409-1423. doi: 10.1002/cam4.1084.

27. Sun G, Wang C, Zhang H. Long non-coding RNA XIST promotes cervical cancer cell epithelial-mesenchymal transition through the $\mathrm{Wnt} /$ beta-catenin pathway. Int J Clin Exp Pathol 2017; 10(2): 2333-2339.

28. Zhang J, Gao Y. CCAT-1 promotes proliferation and inhibits apoptosis of cervical cancer cells via the Wnt signaling pathway. Oncotarget 2017; 8(40): 68059-68070. doi: 10.18632/oncotarget.19155.

29. Lee M, Kim HJ, Kim SW et al. The long non-coding RNA HOTAIR increases tumour growth and invasion in cervical cancer by targeting the Notch pathway. Oncotarget 2016: 7(28): 44558-44571. doi: 10.18632/oncotarget. 10065. 30. Kim HJ, Lee DW, Yim GW et al. Long non-coding RNA HOTAIR is associated with human cervical cancer progression. Int J Oncol 2015; 46(2): 521-30. doi: 10.3892/ijo.2014.2758

31. Zheng P, Xiong Q, Wu Y et al. Quantitative proteomics analysis reveals novel insights into mechanisms of action of long noncoding RNA hox transcript antisense intergenic RNA (HOTAIR) in HeLa Cells. Mol Cell Proteomics 2015; 14(6): 1447-1463. doi: 10.1074/mcp.M114.043984. 32. Zhang L, Qian H, Sha M et al. Downregulation of HOTAIR expression mediated anti-metastatic effect of arte- 
sunate on cervical cancer by inhibiting COX-2 expression. PLoS One 2016; 11(10): e0164838. doi: 10.1371/journal. pone

33. Peng L, Yuan X, Jiang B et al. LncRNAs: key players and novel insights into cervical cancer. Tumour Biol 2016; 37(3): 2779-2788. doi: 10.1007/s13277-015-4663-9. 34. Hu Y, Sun X, Mao C et al. Upregulation of long noncoding RNA TUG1 promotes cervical cancer cell proliferation and migration. Cancer Med 2017; 6(2): 471-482. doi: 10.1002/cam4.994

35. Kim HJ, Eoh KJ, Kim LK et al. The long noncod ing RNA HOXA11 antisense induces tumor progression and stemness maintenance in cervical cancer. Oncotarget 2016; 7(50): 83001-83016. doi: 10.18632/oncotarget.12863.

36. Sun NX, Ye C, Zhao Q et al. Long noncoding RNA-EBIC promotes tumor cell invasion by binding to EZH2 and repressing E-cadherin in cervical cancer. Plos One 2014; 9(7): e100340. doi: 10.1371/journal.pone.0100 340.

37. Sun J, Chu H, Ji J et al. Long non-coding RNA HOTAIR modulates HLA-G expression by absorbing miR-148a in human cervical cancer. Int J Oncol 2016; 49(3): 943-952. doi: 10.3892/ijo.2016.3589
38. Bolha L, Ravnik-Glavac M, Glavac D. Long noncoding RNAs as biomarkers in cancer. Dis Markers 2017; 2017: 7243968. doi: 10.1155/2017/7243968.

39. Zhang J, Yao T, Lin Z et al. Aberrant methylation of MEG3 functions as a potential plasma-based biomarker for cervical cancer. Sci Rep 2017; 7: 6271. doi: 10.1038/s41598-017-06502-7.

40. Campos-Parra AD, Padua-Bracho A, Pedroza-Torres A et al. Comprehensive transcriptome analysis identifies pathways with therapeutic potential in locally advanced cervical cancer. Gynecol Oncol 2016; 143(2): 406-413. doi: 10.1016/j.ygyno.2016.08.327.

\section{Informace z České onkologické společnosti}

Zápis ze schůze výboru České onkologické společnosti konané 30. 10. 2018 ve FN Motol v Praze naleznete na www.linkos.cz. 